\title{
Teatr Dramatyczny im. Aleksandra Węgierki w Bialymstoku w opiniach odbiorców kultury
}

\section{Abstract \\ The Aleksander Wegierko Drama Theater in Bialystok in the Opinions of Recipients of Culture}

The Aleksander Wegierko Drama Theater in Bialystok is one of the oldest and largest cultural institutions in Bialystok. The offer of local institutions allows theater enthusiasts to choose from a variety of proposals. How to reach viewers? How to encourage them to come exactly to the Drama Theater? Until 2012, the research on consumer preferences was not conducted in this institution. Almost seven years ago, in cooperation with the Institute of Sociology of the University of Bialystok and the "SocLab" Foundation, the study was carried out and the report "Diagnosis of participation in culture in the Podlasie Voivodship" was create. The aim of the whole project was to learn about the cultural needs of the inhabitants of the Podlasie region, as well as their opinions on artistic activity and the image of cultural institutions.

After six years - in 2018 - the theater staff decided to ask the viewers again to share their opinions about the institution. In May last year, a study entitled "Theater in the opinions of theviewers" was conducted. Thanks to all the information, the institution managed to find out how audience rate it's offer, what are the expectations regarding future repertoire proposals, as well as from what communication channels viewers obtain information about the operations of the institution. The article aims to describe the most important research results also it presents the distribution channels used to inform about the offer of the Drama Theater.

Keywords: theater, audience, culture, promotion

Słowa kluczowe: teatr, widzowie, kultura, promocja 


\section{Wprowadzenie}

Teatr Dramatyczny im. Aleksandra Węgierki w Białymstoku jest jedną z największych i najstarszych instytucji kultury nie tylko w Białymstoku, ale w całym województwie podlaskim. Historia placówki sięga 1938 roku, kiedy to powstał Teatr Miejski im. Marszałka Józefa Piłsudskiego. Długo wyczekiwana przez białostoczan instytucja nie miała jednak szansy na pełen rozkwit. Po ponad ośmiu miesiącach od rozpoczęcia działalności wybuchła II wojna światowa. Na początku tego niezwykle tragicznego okresu w historii Polski białostocka scena funkcjonowała w pełni. Co ważne i warte podkreślenia, to właśnie w trakcie wojny w Białymstoku pojawił się Aleksander Węgierko - przyszły patron instytucji, który zaczął budować zespół aktorski i nakreślił kierunki artystycznego rozwoju [Kozłowska-Świątkowska 1995, 35-40].

Oficjalnie historia teatru liczona jest jednak od 1944 roku. Jesienią 2019 roku będzie on więc świętować jubileusz 75-lecia. Teatr Dramatyczny nie jest jedyną instytucją artystyczną działającą w stolicy województwa podlaskiego. Aktynie działa tu ceniony na całym świecie Białostocki Teatr Lalek, Opera i Filharmonia Podlaska - Europejskie Centrum Sztuki w Białymstoku, Teatr Szkolny Wydziału Sztuki Lalkarskiej Akademii Teatralnej im. Aleksandra Zelwerowicza w Warszawie, Uniwersyteckie Centrum Kultury, a w położonym nieopodal Supraślu - znany i ceniony Teatr „Wierszalin”.

Dość zróżnicowana oferta teatralna Białegostoku sprawia, że miłośnicy tej sztuki mogą wybierać spośród wielu spektakli realizowanych przez poszczególne instytucje. Każdy z podmiotów upowszechniających sztukę teatralną stara się wyróżnić i zbudować atrakcyjny repertuar, aby ze swoimi propozycjami dotrzeć do jak najszerszego grona odbiorców. Jakimi kanałami dystrybuować informacje o wydarzeniach? Jak zachęcić widzów do wyboru oferty Teatru Dramatycznego? W artykule zostanie podjęta analiza dotychczasowych badań przeprowadzonych przez instytucję oraz ukazanie obrazu placówki widzianego oczami odbiorców. Ważnym aspektem będzie próba udzielenia odpowiedzi na pytanie: w jakim stopniu opinie widzów oraz osób, które rzadziej korzystają z oferty instytucji, zostały uwzględnione w codziennym funkcjonowaniu Teatru Dramatycznego? Jakie refleksje i wnioski wynikają z ocen osób, które są uczestnikami życia kulturalnego w Białymstoku? Skąd odbiorcy czerpią wiedzę na temat repertuaru teatru i jak go oceniają?

\section{Badania kultury - badanie teatru}

Badania odbiorców kultury są coraz częściej spotykaną praktyką w polskich instytucjach. Stałą aktywność w tym zakresie prowadzi Narodowe Centrum Kultury. Gdański Instytut Kultury Miejskiej posiada własny Dział Badań i Rozwoju, który prowadzi badania w Obserwatorium Kultury, tworzy raporty, organizuje konferencje 
dla sektora kultury i $\mathrm{NGO}^{1}$. W ramach Regionalnego Instytutu Kultury w Katowicach funkcjonuje Obserwatorium, które prowadzi działalność badawczo-rozwojową i etnologiczną. Efektami prac tego działu są „diagnozy społeczne, mapowanie zasobów potencjałów kulturotwórczych oraz narzędzia edukacyjne”2. Liczba uczestników organizowanej przez Uniwersytet Jagielloński konferencji naukowej „Badania publiczności w instytucjach kultury” pokazuje, że ta sfera funkcjonowania placówek cieszy się coraz większym zainteresowaniem zarówno badaczy, jak i praktyków. Jednocześnie jednak wciąż nie jest to standardowa aktywność, a jednym z kluczowych problemów, uniemożliwiającym działalność badawczą, jest brak odpowiednich zasobów kadrowych i środków finansowych. Poznawanie opinii widzów, melomanów czy uczestników wystaw jest jednak niezwykle istotne, jeśli chcemy zoptymalizować działalność naszej instytucji. Przeprowadzone w Krakowie badania są tego najlepszym dowodem. Dzięki nim udało się poznać oceny ankietowanych na temat jakości obsługi w krakowskich instytucjach, tematyki i programu wydarzeń, lokalizacji placówek, godzin ich otwarcia, cen biletów czy źródeł informacji o ofercie [Gaweł, Skowron, Szostak 2019: 47-49].

Do 2012 roku w białostockim Teatrze Dramatycznym nie były realizowane żadne badania odbiorców. Dopiero niemal siedem lat temu, w partnerstwie z Instytutem Socjologii Uniwersytetu w Białymstoku oraz z Fundacją Laboratorium Badań i Działań Społecznych SocLab, zostało zrealizowane badanie i powstał raport „Diagnoza partycypacji w kulturze w województwie podlaskim”. Celem całego projektu było dostarczenie wiedzy z zakresu potrzeb kulturalnych mieszkańców województwa podlaskiego, określenie wizerunku instytucji kulturalnych, w tym Teatru Dramatycznego, a także ocena ich działalności artystycznej [Poleszczuk et al. 2012: 7].

Szczegółowe cele realizacji projektu odnosiły się do chęci poznania cech społeczno-demograficznych odbiorców kultury w województwie podlaskim (w tym widzów Teatru Dramatycznego). Badacze postawili przed sobą zadanie ustalenia, jakie są główne przyczyny niekorzystania z tzw. kultury wysokiej, za którą uznano teatr, a także jakie wydarzenia kulturalne, realizowane na przykład przez Teatr Dramatyczny, mogłyby zachęcić nie-uczestników do aktywności. Badanie miało na celu zanalizowanie preferencji i potrzeb kulturalnych mieszkańców, w tym aktualnych i potencjalnych widzów Teatru Dramatycznego. Ponadto zamierzano dokonać analizy silnych i słabych stron marki „Teatr Dramatyczny” oraz zbadać jej rozpoznawalność. Ważną część badania stanowił pomiar satysfakcji i cena oferty, a także weryfikacja lojalności, zaangażowania i przywiązania aktualnej publiczności Teatru Dramatycznego. Ważnym aspektem badania była analiza źródeł informacji o wydarzeniach teatralnych, ocena skuteczności dotychczasowych strategii

1 Zob. http://ikm.gda.pl/projekty/ [odczyt: 15.05.2019].

2 Zob. https://rik.katowice.pl/obserwatorium/badania-i-rozwoj/ [odczyt: 15.05.2019]. 
marketingowo-promocyjnych oraz wybór kluczowych cech, niezbędnych w przyszłej komunikacji [Poleszczuk et al. 2012: 7].

Projekt badawczy, na którego realizację środki zostały pozyskane z Ministerstwa Kultury i Dziedzictwa Narodowego, miał wielowymiarowy charakter. W celu zdobycia niezbędnych danych wykorzystano różnorodne metody i techniki badawcze. Informacje dotyczące oceny funkcjonowania Teatru Dramatycznego otrzymano dzięki przeprowadzeniu badania PAPI wśród 221 użytkowników „okazjonalnych” i 275 odbiorców „stałych” (łącznie 500 osób) oraz dzięki badaniu CAWI wśród 350 internautów. Ponadto dwa z czterech zogniskowanych wywiadów grupowych (FGI) dotyczyły oferty Teatru. Jeden z wywiadów grupowych został przeprowadzony wśród odbiorców tzw. kultury wysokiej, którzy na co dzień nie korzystają z oferty instytucji. Celem badania było poznanie powodów i przyczyn nieuczestniczenia w wydarzeniach proponowanych przez Teatr. Drugi z wywiadów objął natomiast widzów. Ich opinie pozwoliły poznać postrzeganie przez nich Teatru, a także ich wizje zmian oraz ulepszenia funkcjonowania instytucji [Poleszczuk et al. 2012: 31-35]. W rezultacie realizacji zadania pracownikom udało się zyskać wiedzę ułatwiającą kształtowanie oraz poprawę polityki artystycznej i promocyjnej.

$\mathrm{W}$ raporcie $\mathrm{z}$ badania dostępne są szczegółowe analizy zebranego materiału ${ }^{3}$. Diagnoza zawiera niezwykle istotne informacje na temat uczestnictwa mieszkańców województwa podlaskiego w sferze kultury. Ponadto z wyników badań można poznać charakterystykę użytkowników Teatru Dramatycznego. Badacze zrekonstruowali tzw. rytuał wyjścia do teatru i przedstawili główne czynniki decydujące o wyborze przez widzów konkretnego spektaklu. Ważną część raportu stanowi ocena działalności instytucji, opis preferencji repertuarowych oraz kierunki, w jakich powinna być poszerzana oferta wydarzeń kulturalnych. W niniejszym artykule zostaną zaprezentowane jedynie najistotniejsze wnioski z przeprowadzonej analizy: kluczowe dla podejmowania decyzji i działań promocyjnych oraz marketingowych.

\section{Teatr w opiniach odbiorców}

Jednymi z najistotniejszych wniosków, jakie płynęły z przeprowadzonej diagnozy, były te dotyczące zagadnień wizerunkowych. Dzięki badaniu udało się ustalić, jakie cechy przypisywano marce „Teatr Dramatyczny”, a więc jaki był obraz instytucji w oczach jej odbiorców. Teatr Dramatyczny uznany został za miejsce reprezentacyjne. Placówkę tę najczęściej określano jako: „miejsce, w którym wypada bywać”, „dla ludzi z klasą", „wizytówkę miasta” czy po prostu „wartą polecenia”. Z ocen widzów wyłonił się obraz instytucji o wysokiej jakości i tradycji. Uznano, iż cechy

3 Raport dostępny jest na stronie internetowej Teatru Dramatycznego: https://dramatyczny.pl/ projekty/obserwatorium-kultury/ [odczyt: 15.05.2019]. 
te działają na odbiorców nobilitująco. Co istotne, 35\% respondentów dostrzegło również, że potencjał teatru wciąż nie do końca był wykorzystany. Osoby te czuły niedosyt i wskazywały na możliwości poszerzenia działalności artystycznej instytucji [Poleszczuk et al. 2012: 114].

Badacze zauważyli analogiczny stosunek do teatru także wśród osób, które wzięly udział w badaniach jakościowych. Jednym z elementów badań grupowych była gra projekcyjna, mająca na celu stworzenie opisu Teatru Dramatycznego w formie personalizacji. Teatr Dramatyczny okazał się uosobieniem „starszego, eleganckiego mężczyzny, z cylindrem i laseczką, który jest mądry, doświadczony i może być autorytetem. Na przyjęcie zorganizowane przez Teatr Dramatyczny zaproszono inne teatry, które mogłyby „uczyć się klasy i dobrych manier od Teatru Dramatycznego". Wizerunek uzyskany w czasie zogniskowanych wywiadów grupowych okazał się spójny z opiniami pozyskanymi innymi metodami. Także uczestnicy badania jakościowego uznali, że Teatr Dramatyczny jest miejscem związanym z elegancją, tradycją, do którego przychodzą ludzie kulturalni [Poleszczuk et al. 2012: 114].

Znacznie gorszy obraz Teatru Dramatycznego wyłonił się z opinii osób, które na co dzień nie korzystały z oferty instytucji. Jak zaznaczyli sami badacze, wizerunek ten nie był oceniany tak wyraziście i spójnie, jak w przypadku użytkowników teatru. Respondenci często udzielali odpowiedzi wymijających, na przykład „nie wiem” lub ,ani się zgadzam, ani nie zgadzam”. W każdej badanej grupie Teatr Dramatyczny został spersonifikowany jako „starszy mężczyzna, w eleganckim, choć już trochę zużytym fraku, z laseczką". Przywoływana nobliwość wizerunku miała różne konotacje: „od mądrego nauczyciela do pejoratywnie ocenianego mieszczanina” [Poleszczuk 2012: 114].

Jakie najważniejsze wnioski płyną z analizy wizerunku instytucji i czy zostały one uwzględnione przez jej zarządzających? Wśród widzów Teatru Dramatycznego wizerunek tej placówki okazał się bardzo pozytywny. Zdaniem autorów diagnozy teatr dla jego użytkowników jest źródłem silnej identyfikacji. Wyrażana jest ona poprzez wysoki stopień lojalności wobec Teatru. Autorzy raportu zarekomendowali włączanie widzów Teatru Dramatycznego jako „ambasadorów Teatru” w kampanie reklamowe skierowane do osób, które nie korzystają z oferty instytucji. Fani teatru mogliby zostać zaangażowani w budowę pozytywnego wizerunku instytucji, na przykład poprzez swoją aktywność w internecie czy udział w wydarzeniach o charakterze partycypacyjnym [Poleszczuk et al. 2012: 141].

Niestety, do tej pory nie udało się w pełni wdrożyć powyższych zaleceń. Teatr prowadzi codzienną aktywność w mediach społecznościowych, które na przestrzeni kilku ostatnich lat stały się głównym kanałem komunikacyjnym z widzami. Poprzez ich komentarze czy wiadomości możliwe jest zebranie opinii na temat bieżącej działalności instytucji. W przyszłości z pewnością warto pomyśleć o bardziej kompleksowym programie, służącym wyłonieniu ambasadorów teatru. Być może warto 
wybrać ich spośród „liderów wśród fanów” na portalu Facebook, a więc z grona osób najbardziej zaangażowanych w ramach tego kanału komunikacyjnego.

Zdaniem badaczy widzowie Teatru Dramatycznego wykazywali potrzebę zwiększania wiedzy na tematy związane z wydarzeniami odbywającymi się w instytucji. Placówce zarekomendowano umożliwienie odbiorcom pogłębiania wiedzy na temat teatru, poszczególnych spektakli oraz innych wydarzeń. Wśród podpowiedzi znalazły się następujące pomysły: wykorzystanie różnorodnych źródeł przekazu, takich jak: internet, spotkania $\mathrm{z}$ twórcami spektakli oraz udostępnianie większej liczby informacji związanych $\mathrm{z}$ przedstawieniami na stronach internetowych czy w newsletterze [Poleszczuk et al. 2012: 153].

Dzięki rozwojowi mediów społecznościowych przekazywanie widzom informacji stało się znacznie prostsze i szybsze. Teatr korzysta z komunikacji między innymi poprzez Facebook, Instagram czy newsletter. Na bieżąco udzielane są odpowiedzi poprzez komunikator Messenger, dzięki czemu widzowie mogą otrzymać odpowiedzi na pytania $\mathrm{w}$ danym momencie i podjąć decyzję o ewentualnym zakupie biletów. W 2013 roku wprowadzono system sprzedaży biletów, który w 2017 roku został zmodernizowany i przygotowany w taki sposób, aby osoba dokonująca zakupu biletów mogła znaleźć w jednym miejscu wszystkie niezbędne informacje na temat przedstawień. Także w 2013 roku uruchomiono nowy, bardziej czytelny serwis internetowy. W 2019 roku powstała nowa strona, która została zaprojektowana na podstawie analiz i statystyk, dzięki którym udało się ustalić, jakie informacje są tymi, których widzowie najczęściej poszukują. Dzięki przeprojektowaniu udało się zoptymalizować funkcjonalność witryny, tak aby w pełni odpowiadała oczekiwaniom użytkowników.

Zgodnie z wynikami diagnozy wizerunek Teatru Dramatycznego wśród mieszkańców województwa był mniej wyrazisty i spójny. Dominowały w nim negatywne cechy, dlatego wśród zaleceń badaczy pojawiła się propozycja zwiększenia rozpoznawalności marki Teatru Dramatycznego, a także poprawienie wizerunku oraz dostępności instytucji. Aby osiągnąć powyższe, uznano za konieczne zintensyfikowanie kampanii wizerunkowej w całym województwie podlaskim z wykorzystaniem odpowiednich kanałów informacyjnych (m.in. prasy lokalnej, ogłoszeń, plakatów). W kampanii wizerunkowej Teatr powinien zwracać szczególną uwagę na historię i długą tradycję istnienia. Instytucja powinna także wyeksponować pozytywne elementy budynku teatru, tak aby stał się on ogniwem wizerunku [Poleszczuk et al. 2012: 153].

Zintensyfikowanie działań promocyjnych na obszarze całego województwa niestety okazało się niemożliwe. Teatr Dramatyczny posiada ograniczone środki budżetowe, które przeznacza na działania reklamowe. W celu dotarcia do odbiorców spoza Białegostoku instytucja rozpoczęła działania z zakresu media relations, skierowane do dziennikarzy z różnych części województwa, w tym głównie z Suwalszczyzny. Partnerem medialnym teatru stał się na przykład portal internetowy 
„Niebywałe Suwałki”, który na swoich łamach na bieżąco informuje czytelników o propozycjach repertuarowych Teatru Dramatycznego. Do grona partnerów dołączył także „Podbiałostocki Kurier Sąsiedzki bia.24” - gazeta dystrybuowana w gminach zlokalizowanych nieopodal Białegostoku. Dzięki nawiązaniu współpracy z gazetą informacje o wydarzeniach teatralnych docierają do odbiorców, którzy mieszkają dość blisko Białegostoku, a więc są potencjalnymi widzami Teatru Dramatycznego.

W 2018 roku minęło 80 lat od wybudowania budynku Teatru Dramatycznego. Jubileusz ten stał się okazją do przypomnienia odbiorcom bogatej historii instytucji. Dzięki dotacji MKiDN udało się stworzyć i zainicjować działalność archiwum cyfrowego, w którym rozpoczęto publikowanie zdigitalizowanych materiałów znajdujących się w archiwum artystycznym. W bogatym zbiorze placówki znajdują się ogłoszenia, afisze, programy, plakaty i zdjęcia spektakli, które prezentowane były na scenach teatru od 1944 roku. Ponadto powstała książka o historii białostockiego teatru, której wydanie poprzedzone było emisją filmowych zapowiedzi pod hasłem „Teatr - wczoraj i dziśs". Przełom 2018 i 2019 roku stał się okazją do przypomnienia bogatej tradycji teatru. W działaniach komunikacyjnych służy temu hasło „Niech żyje teatr!”, systematycznie wykorzystywane w mediach społecznościowych, głównie na Instagramie.

Przy okazji działań przypominających o bogatej historii teatru instytucja przypomniała obiorcom o długiej tradycji i smutnych losach budynku, w którym się znajduje. Teatr Dramatyczny wciąż czeka na gruntowny remont, stąd wygląd wnętrza i charakter teatralnej przestrzeni niestety nie wpływają zachęcająco na potencjalnych widzów. Budynek posiada jednak swoje walory architektoniczne, jest ciekawym przykładem architektury modernistycznej, dlatego rozpoczęto starania o przywrócenie mu należnego miejsca w świadomości mieszkańców miasta. Rycina budynku znajduje się między innymi na kartach świątecznych teatru, a także na innych materiałach promocyjnych, jak: kubki, torby czy notesy. Dodatkową okazją do atrakcyjnego wykorzystania architektury budynku będzie zbliżający się jubileusz funkcjonowania instytucji i planowane otwarcie wystawy poświęconej temu miejscu.

Na przestrzeni kilku ostatnich lat Teatr Dramatyczny dokonał także istotnych zmian w zakresie identyfikacji. Instytucja stara się dbać o spójną komunikację wizualną, opartą na logo autorstwa prof. Andrzeja Strumiłły. Autorami wszystkich teatralnych plakatów są artyści graficy: Agnieszka Popek-Banach i Kamil Banach. Ich prace, nagradzane na ogólnopolskich konkursach, zapewniają Teatrowi przejrzystość i rozpoznawalność.

Ogólna analiza działalności Teatru Dramatycznego przez jego użytkowników przyniosła następujące refleksje: widzowie, co zauważono powyżej, nisko oceniali przede wszystkim infrastrukturę teatru. Wprowadzenie zmian w infrastrukturze (zarówno jeśli chodzi o sam budynek, jak i jego wyposażenie) jest warunkiem 
koniecznym dalszego funkcjonowania instytucji [Poleszczuk et al. 2012: 153]. Zmiany w tej sferze dokonywane są poprzez wspomniane eksponowanie pozytywnych elementów budynku w działaniach wizerunkowych teatru, a także poprzez systematyczny zakup nowego wyposażenia, które ma poprawiać komfort odbioru spektakli przez widzów. W tym celu w ostatnich latach dokonano między innymi zakupu nowej konsoli akustycznej czy nowego sprzętu nagłośnieniowego.

"Nie-widzowie”, a więc potencjalni obiorcy, negatywnie oceniali przede wszystkim samą ofertę instytucji oraz liczbę premier. Zdaniem autorów diagnozy Teatr powinien wprowadzić większą ofertę wydarzeń kulturalnych oraz nowy repertuar. Przygotowując nowe działania artystyczne, powinien „brać pod uwagę spójność nowej/zmienionej tożsamości marki Teatru Dramatycznego i otwartość różnych grup widzów na różne nowe formy działania Teatru Dramatycznego" [Poleszczuk et al. 2012: 153]. W 2012 roku, a więc już po powstaniu diagnozy, nastąpiła zmiana artystyczna instytucji. Już w 2012 roku przyniosła ona spadek liczby widzów, który najbardziej zauważalny był w 2015 roku. Wówczas instytucję odwiedziło 30438 osób. Dla porównania - w 2011 roku było to 53730 widzów (szczegółowe dane od 2010 do 2019 roku prezentuje tabela 1). Po dokonaniu kolejnych zmian repertuarowych 2017 rok przyniósł rekordową liczbę zagranych spektakli oraz widzów, którzy je obejrzeli. Aktorzy zagrali łącznie 351 przedstawień, które obejrzało 65760 osób. Szczegółowe dane od 2010 do 2019 roku prezentuje tabela 1 .

Tabela 1. Liczba spektakli i widzów w latach 2010-2018

\begin{tabular}{|c|c|c|c|c|c|c|c|c|c|}
\hline Rok & 2010 & 2011 & 2012 & 2013 & 2014 & 2015 & 2016 & 2017 & 2018 \\
\hline Spektakle & 344 & 288 & 257 & 272 & 264 & 272 & 241 & 351 & 293 \\
\hline
\end{tabular}

Źródło: opracowanie własne na podstawie corocznych sprawozdań Teatru Dramatycznego.

Okazało się więc, że nowe propozycje artystyczne nie wpłynęły na zwiększenie zainteresowania ofertą Teatru Dramatycznego. Ponieważ zadaniem jedynej tego typu instytucji w makroregionie jest zapewnienie różnorodnej oferty, która będzie adresowana do szerokiego grona odbiorców, instytucja podjęła próbę stworzenia nowych inicjatyw artystycznych. W 2017 roku zorganizowano pierwszą edycję festiwalu „Kierunek Wschód” - przeglądu spektakli prezentującego kulturę pogranicza, w tym przedstawienia zza wschodniej granicy Polski. Wydarzenie realizowane jest z myślą o poszerzeniu oferty kulturalnej teatru, ale także realizacji międzynarodowej idei Partnerstwa Wschodniego, a celem festiwalu jest zacieśnianie współpracy kulturalnej państw z obszaru Partnerstwa oraz ośrodków kultury zlokalizowanych na pograniczach. Zróżnicowaniu oferty instytucji służy także tzw. Scena PracOFFnia. W jej ramach swoje spektakle mogą prezentować twórcy 
niezależni. W ostatnich latach ogromnym zainteresowaniem widzów cieszyły się spektakle Teatru PAPAHEMA.

Aby sprawdzić, jak odbiorcy oceniają aktualną ofertę instytucji, postanowiono ponownie zwrócić się do nich z prośbą o podzielenie się refleksjami na temat działalności placówki. Po sześciu latach od powstania diagnozy, na przełomie maja i czerwca 2018 roku, pracownicy we własnym zakresie przeprowadzili badanie zatytułowane „Teatr w opiniach widzów”. Jego głównym celem było poznanie aktualnych ocen widzów dotyczących funkcjonowania instytucji, a także uzyskanie wiedzy na temat częstotliwości korzystania $\mathrm{z}$ oferty repertuarowej, oceny godzin prezentacji spektakli czy sposobu dokonywania zakupu biletów. Ponadto celem było ustalenie, jakie są główne kanały informacji, z jakich widzowie czerpią wiedzę na temat Teatru Dramatycznego, a także jakie spektakle najchętniej oglądaliby na teatralnych scenach w kolejnych latach.

Praktycznym celem badania była więc chęć uzyskania wiedzy, dzięki której w przyszłości będzie można usprawnić pracę instytucji, dostosować godziny prezentacji spektakli do oczekiwań i potrzeb odbiorców, a także opracować taki plan rozwoju artystycznego, który pozwoli na zachowanie przyjętej wizji, przy jednoczesnym uwzględnieniu potrzeb zgłoszonych przez widzów Teatru Dramatycznego.

Badanie zostało przeprowadzone $\mathrm{z}$ wykorzystaniem kwestionariusza ankiety. Kwestionariusz został przygotowany w dwóch wersjach. Wariant tradycyjny został wydrukowany i był rozdawany widzom przed i po spektaklach. Wersja internetowa kwestionariusza została umieszczona na stronie internetowej teatru ( $w$ formularzu Google). Łącznie w badaniu wzięło udział 138 osób: 43 wypełniły ankietę drukowaną, a 95 wersję elektroniczną.

Pierwsze z pytań, które zostało zawarte w kwestionariuszu ankiety, brzmiało: „Jak często chodzi Pani/Pan do Teatru Dramatycznego?”. Najwięcej - 58 osób $(38,4 \%)$ - odpowiedziało, że odwiedza teatr raz na kwartał. Drugą w kolejności grupę stanowiły osoby, które z oferty instytucji korzystają raz na pół roku (27 osób - 19,6\%). Nieco rzadziej wybierano odpowiedź „raz w miesiącu” (23 - 16,7\%). Najmniej liczebnymi grupami były te, które udzieliły odpowiedzi: „raz w roku” (16-11,6\%), „rzadziej” (11-8\%) oraz „kilka razy w miesiącu” (8-5,8\%). Odpowiedzi na pytanie prezentuje wykres 1 . Z zebranych danych wynika, że w badaniu wzięły udział głównie osoby, które nie są stałymi bywalcami instytucji i korzystają z jej oferty raczej sporadycznie.

Z przygotowanej kafeterii respondenci mogli wybrać różnorodne odpowiedzi na kolejne z pytań: skąd czerpie Pani/Pan informacje na temat repertuaru Teatru Dramatycznego? Zebrane odpowiedzi nie sumują się do 138, ponieważ

4 Badanie „Teatr w opiniach widzów” stało się podstawą do napisania pracy dyplomowej autorki, zatytułowanej „Opinie widzów na temat Teatru Dramatycznego im. Aleksandra Węgierki w Białymstoku", która została obroniona w Akademii Humanistyczno-Ekonomicznej w Łodzi. 


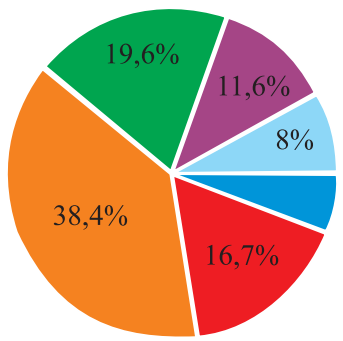

Kilka razy w miesiącu

- Raz w miesiącu

- Raz na kwartał

Raz na pół roku

- Raz w roku

Rzadziej

Wykres 1. Jak często chodzi Pani/Pan do Teatru Dramatycznego? N = 138 odpowiedzi

Źródło: opracowanie własne.

każda osoba mogła zaznaczyć więcej niż jedną odpowiedź. Największym źródłem wiedzy okazała się strona internetowa Teatru. Znajdujące się na niej informacje stanowią źródło wiedzy dla zdecydowanej większości osób $(94-68, \%)$. Drugim kanałem, z którego widzowie czerpią wiedzę na temat propozycji teatralnych, są znajomi oraz rodzina. Informacje o teatrze poprzez najbliższych pozyskuje 57 osób. Dane te potwierdzają, że tzw. marketing szeptany [Brydniak 2011: 153] ma ogromne znaczenie w procesie kształtowania wizerunku instytucji wśród jej potencjalnych odbiorców.

Mniej - 50 osób - korzysta z informacji zamieszczanych na oficjalnym fanpage’u teatru na portalu Facebook. 47 osób wspomniało o plakatach teatralnych, a 42 ogólnie o internecie jako źródle wiedzy. 31 osób korzysta z drukowanego co dwa miesiące repertuaru. 21 osób jako źródło wiedzy wskazało newsletter i tyle samo zaznaczyło ulotki. Rzadziej wymienianymi kanałami informacyjnymi były: radio (13 osób), prasa (10 osób), telewizja (5 osób), czy Instagram (3 osoby). Rozkład procentowy odpowiedzi prezentuje wykres 2 .

Wyniki pokazują, jak bardzo ważnym źródłem informacji jest dzisiaj internet. Kiedy zsumuje się odpowiedzi dotyczące poszukiwania informacji poprzez stronę internetową, Facebook Teatru Dramatycznego czy ogólnie internet, okazuje się, iż jest to główne źródło wiedzy na temat oferty Teatru. Drugim w kolejności są opinie przekazywane przez rodzinę czy znajomych.

Analiza odpowiedzi na kolejne z pytań pozwala stwierdzić, że połowa uczestników badania oceniła ogólnie spektakle Teatru Dramatycznego jako bardzo dobre (69 osób). 54 osoby wystawiły przedstawieniom ocenę dobrą. Nieco mniej osób uznało, że spektakle są przeciętne (11 osób), tylko cztery osoby uznały, że złe, a jedna, że bardzo złe. Procentowy rozkład odpowiedzi prezentuje wykres 3 .

Badani zostali poproszeni także o ocenę poszczególnych spektakli, które znajdują się w repertuarze instytucji. Odpowiadający na ankietę mieli za zadanie ocenić tylko te przedstawienia, które oglądali. Większość z nich zyskała pozytywne oceny. Spektakle, które przez widzów zostały ocenione najwyżej, to: Szalone nożyczki w reżyserii 


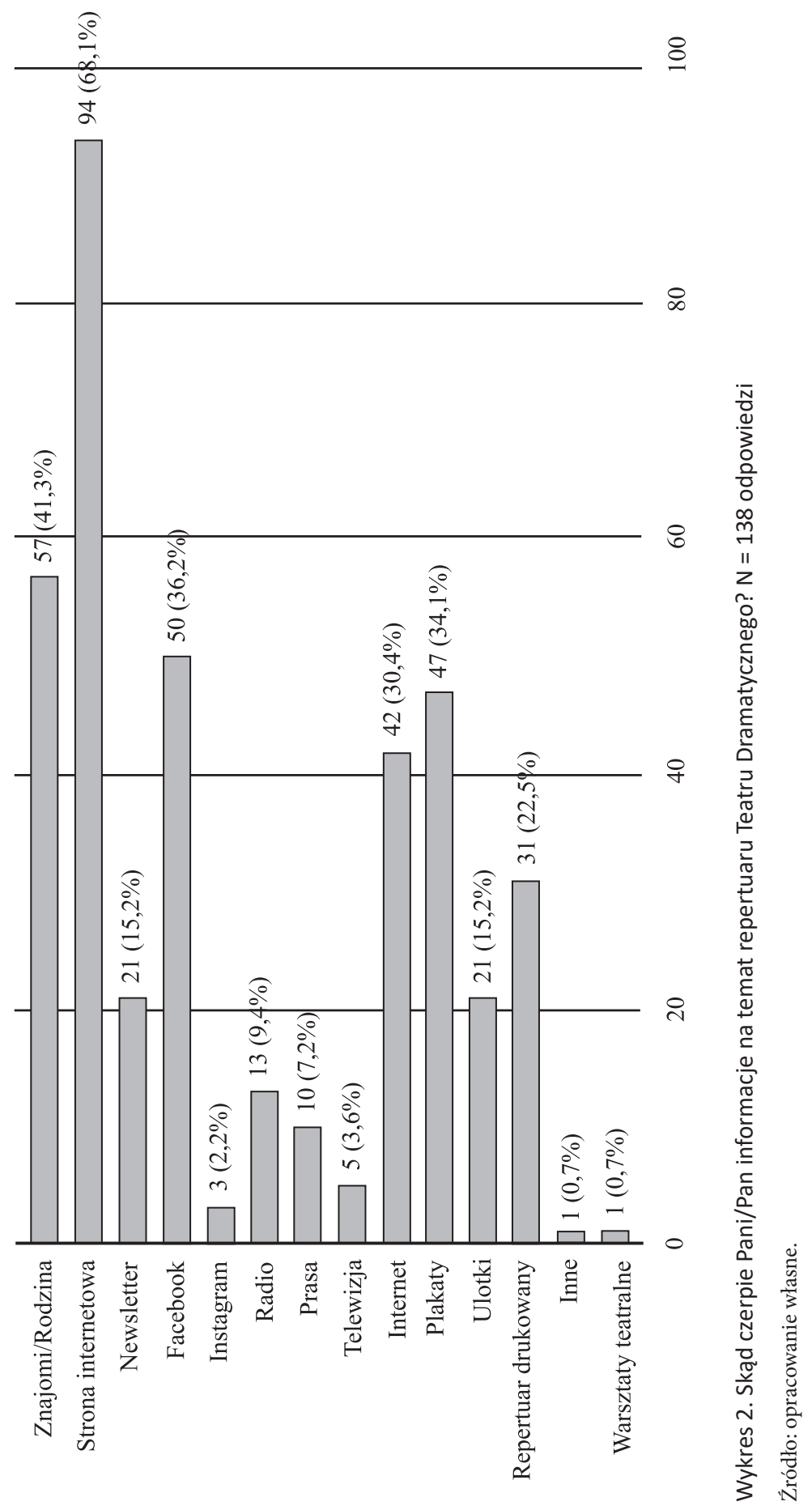




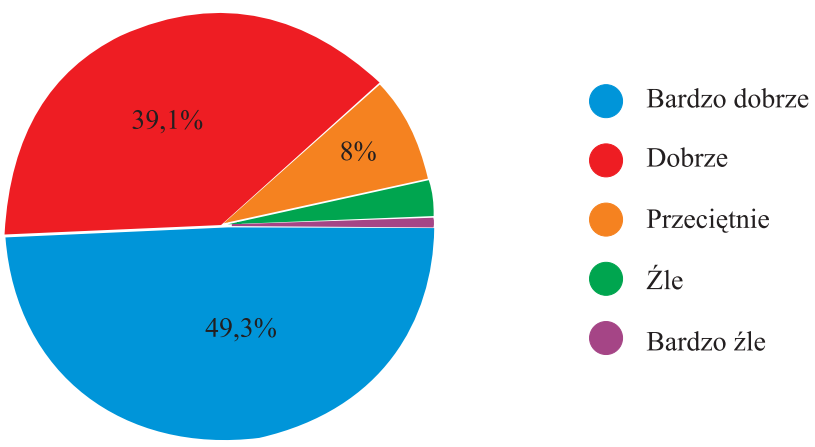

Wykres 3. Jak ogólnie ocena Pani/Pan spektakle Teatru Dramatycznego? N = 138 odpowiedzi Źródło: opracowanie własne.

Piotra Dąbrowskiego - jako bardzo dobre uznane przez 70 widzów, a także Zapiski oficera Armii Czerwonej w reżyserii Andrzeja Jakimca - bardzo dobrze ocenione przez 68 osób. 61 osób uznało za bardzo dobre przedstawienie Kogut w rosole w reżyserii Marka Gierszała oraz Mayday w reżyserii Witolda Mazurkiewicza. Zdaniem 39 osób bardzo dobrym spektaklem jest także Ożenek w reżyserii Piotra Dąbrowskiego, a 32 osoby za bardzo dobre przedstawienie uznały Seks nocy letniej, powstałe pod opieką artystyczną Agnieszki Korytkowskiej-Mazur. Szczegółowe dane dotyczące poszczególnych spektakli prezentują wykresy: 4, 4a, 4b i 4c.

Analiza zebranych odpowiedzi potwierdza, że większość osób biorących udział $\mathrm{w}$ badaniu to widzowie, którzy dosyć rzadko korzystają $\mathrm{z}$ oferty Teatru Dramatycznego. Jak pokazują wyniki, znaczna większość badanych nie oglądała wszystkich propozycji repertuarowych instytucji. Wśród spektakli znalazły się takie, które obejrzała niewielka liczba osób. Co ważne, wśród zebranych opinii właściwie mniejszość stanowią te negatywne. Obejrzane przez widzów przedstawienia zazwyczaj otrzymywały ocenę dobrą lub bardzo dobrą. Spektakle, które zyskały największą liczbę wskazań jako „bardzo słabe”, to Kogut w rosole i Balladyna. W przypadku obydwu sztuk oceny takiej dokonało jednak jedynie po 5 osób. Spektakle, które zyskały najwięcej ocen jako „słabe”, to z kolei: Opowieści o zwyczajnym szaleństwie (9 wskazań), Seks nocy letniej (8 wskazań), a także Napis, Ożenek i Popiełuszko (po 6 wskazań).

$\mathrm{Z}$ uwagi na chęć poznania sposobu zakupu biletów przez widzów respondenci zostali poproszeni o odpowiedź na pytanie: w jaki sposób zakupują bilety na spektakle. Połowa badanych dokonuje zakupu biletów na spektakle zarówno drogą tradycyjną - w kasie, jak i przez internet. Osób, które wskazały odpowiedź uwzględniającą te dwie metody zakupu, było 71.36 uczestników badania kupuje bilety wyłącznie przez stronę internetową, a 31 tylko w kasie. Rozkład procentowy odpowiedzi prezentuje wykres 5 . 

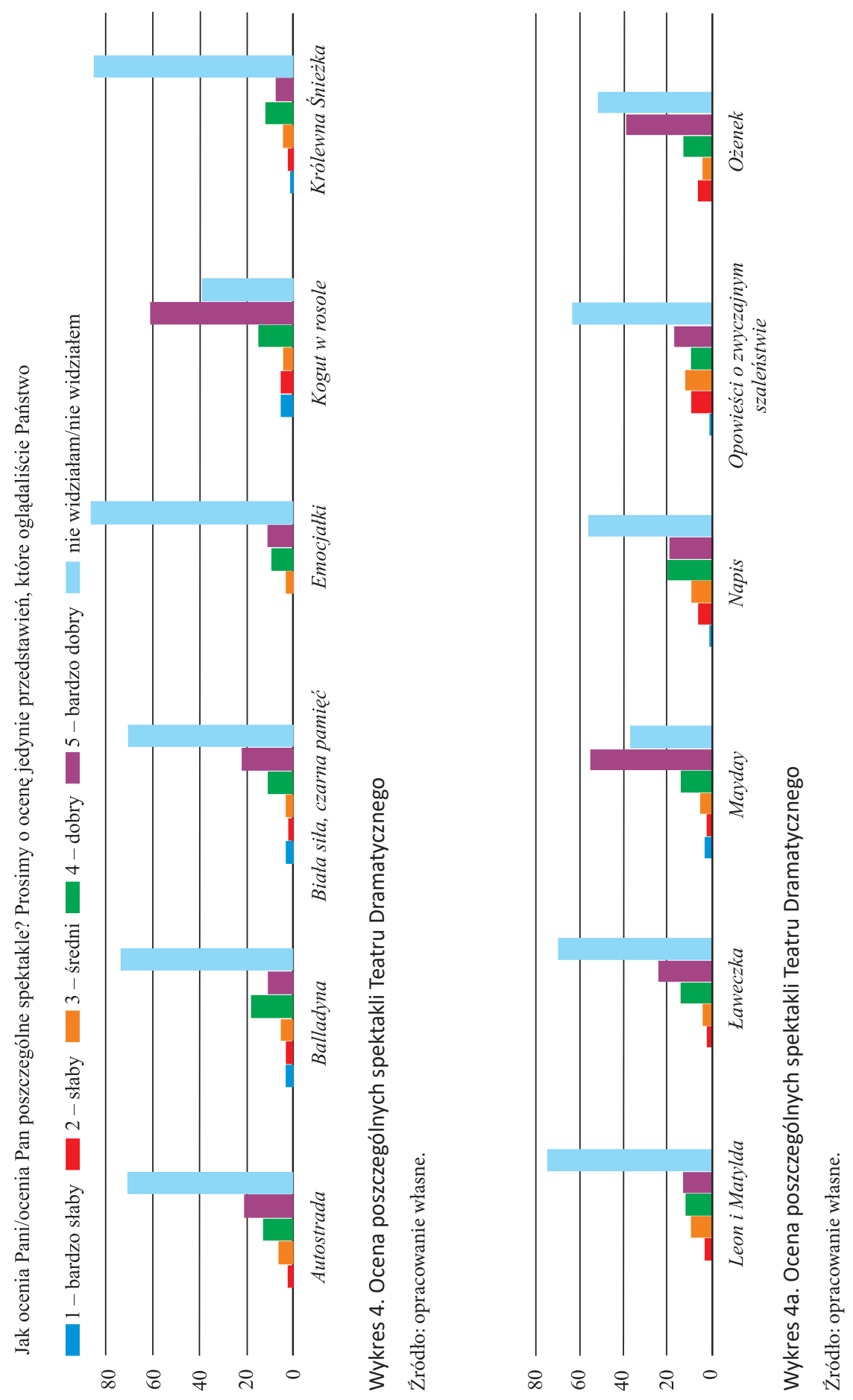


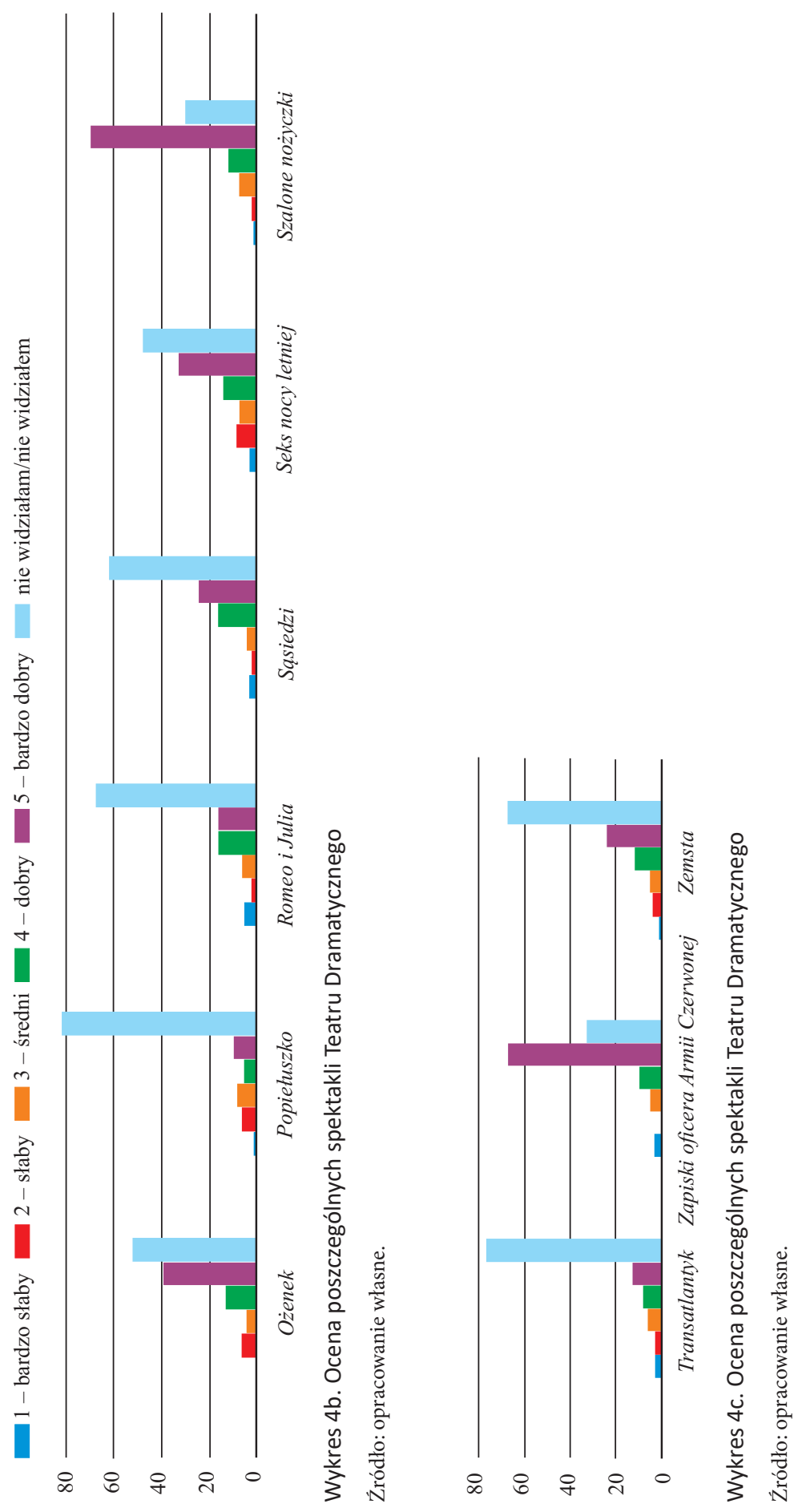




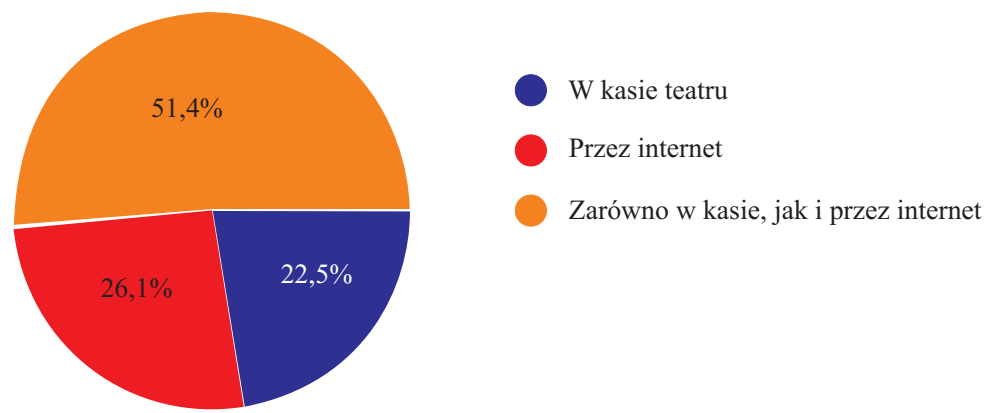

Wykres 5. Sposób zakupu biletów na spektakle Teatru Dramatycznego ( $N=138)$

Źródło: opracowanie własne.

Respondenci zostali poproszeni także o wskazanie godzin prezentacji spektakli, które ich zdaniem są najdogodniejsze. Zarówno na Scenie Dużej, jak i Scenie Kameralnej najdogodniejszą godziną okazała się 19.00. Nieco rzadziej wskazywano na godzinę 18.00. Najmniej odpowiedzi otrzymały wcześniejsze godziny, tj. 16.00 i 17.00, a także godziny wieczorne - 20.00. Rozkład odpowiedzi prezentuje wykres 6 . Analiza odpowiedzi pokazuje, że po remoncie instytucji warto rozważyć zmianę godzin prezentacji spektakli, gdyż aktualnie te na Scenie Dużej prezentowane są gównie ok. godz. 17.00, a przedstawienia na Scenie Kameralnej - ok. godz. 20.00.

Jako podsumowanie badania uczestnikom zadano pytanie: „Czy poleciłaby Pani/poleciłby Pan Teatr Dramatyczny swoim bliskim/znajomym etc.”. Przeważająca większość osób uznała, że zdecydowanie poleciłaby ofertę teatru swoim bliskim i znajomym. Aż 120 osób na tak postawione pytanie udzieliło odpowiedzi pozytywnej. Tylko 9 osób uznało, że nie wie, a 8 odpowiedziało, że nie poleciłoby oferty tej instytucji. Procentowy rozkład uzyskanych odpowiedzi prezentuje wykres 7.

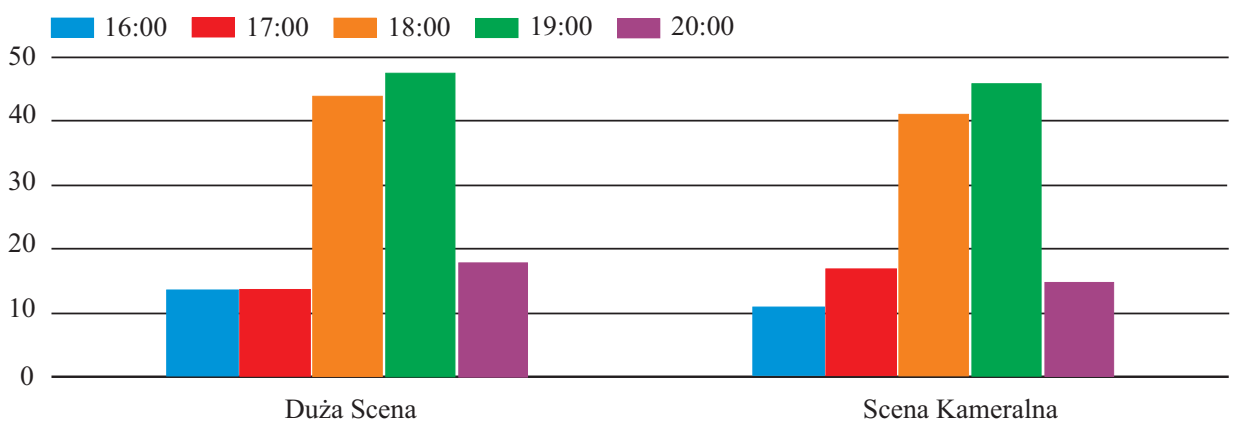

Wykres 6. Preferowane godziny prezentacji spektakli

Źródło: opracowanie własne. 


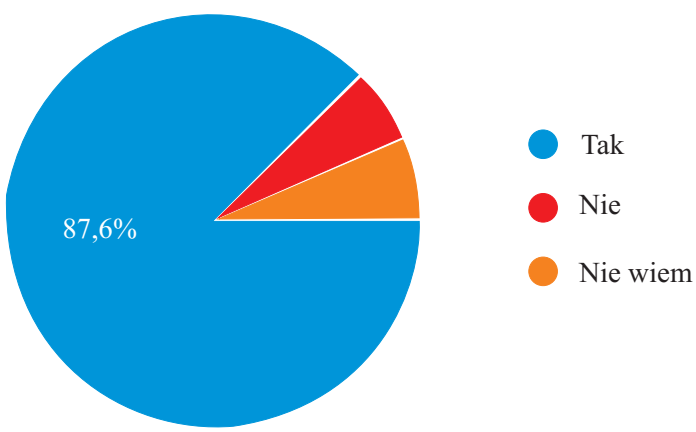

Wykres 7. Czy poleciłaby Pani/poleciłby Pan Teatr Dramatyczny swoim bliskim, znajomym? ( $N=137)$ Źródło: opracowanie własne.

Oprócz pytań zamkniętych uczestnicy badania zostali poproszeni o odpowiedź na jedno pytanie otwarte. Widzowie mieli okazję opowiedzieć o spektaklach, które chcieliby obejrzeć w Teatrze Dramatycznym. Spośród 138 osób, które zdecydowały się na udział w badaniu, ponad połowa podzieliła się swoimi opiniami na temat przedstawień, które chciałaby zobaczyć na scenach „Węgierki” w przyszłości.

Trzy grupy spektakli, które zostały uznane za najbardziej pożądane, to: klasyka, komedie i spektakle współczesne. 28 osób uznało, że najchętniej obejrzałoby przedstawienia klasyczne, zarówno twórców polskich, jak i zagranicznych. Wśród tytułów, które pojawiały się w wypowiedziach, znalazły się takie jak: Makbet, Hamlet Williama Szekspira, Mistrz i Małgorzata Michaiła Bułhakowa, Klatwa Stanisława Wyspiańskiego, Rewizor Nikołaja Gogola, Śluby panieńskie Aleksandra Fredry, ale także Moralność pani Dulskiej Gabrieli Zapolskiej, Tango Sławomira Mrożka. Badani wspominali także o innych dziełach Szekspira, Fredry, Gogola, Czechowa. Widzowie podkreślali, że chętnie oglądaliby więcej spektakli kostiumowych oraz klasyki, ale $\mathrm{w}$ tradycyjnej formie.

27 razy badani wymieniali spektakle określane jako „współczesne”. W wypowiedziach znalazły się takie tytuły: Księżyc i magnolie Rona Hutchinsona, Samotny zachód Martina McDonagha, Merylin Mongoł Nikołaja Kolady, Nasza klasa Tadeusza Słobodzianka czy przedstawienia już wcześniej grane na scenach Teatru Dramatycznego: Tango Prohibicja i Big bit Milicja, Biała siła, czarna pamięć, Między nami dobrze jest, Gąska Nikołaja Kolady czy spektakle znajdujące się aktualnie w repertuarze, m.in: Opowieści o zwyczajnym szaleństwie Petra Zelenki, Autostrada Michaela McKeevera, czy Napis Geralda Syberiasa.

Komedie były trzecimi w kolejności najczęściej wymienianymi gatunkami (26). Widzowie podkreślali, że chętnie oglądaliby spektakle $\mathrm{z}$ humorem, lekkie, przy których człowiek zapomina o trudach codziennego życia. W wypowiedziach respondentów pojawiła się chęć uczestnictwa w przedstawieniach interaktywnych, 
w których widzowie biorą czynny udział, na przykład Szalone nożyczki Paula Pörtnera. Inne tytuły, które zostały wskazane, to: Mayday Raya Cooneya, Co widział kamerdyner? Joe Ortona, Przyjazne dusze Pam Valentine czy Trzy razy łóżko Jana Jakuba Należytego.

Pozostałe gatunki teatralne były wskazywane znacznie rzadziej. Czterokrotnie wspomniano o dramatach i tragediach bez podania konkretnych tytułów. Również czterokrotnie wspomniane były spektakle muzyczne i musicale, takie jak Skrzypek na dachu czy Chicago. Dwie osoby uznały, że najchętniej obejrzałyby przedstawienia ambitne, zaskakujące, alternatywne, w groteskowy sposób komentujące rzeczywistość. Tylko jedna osoba uznała, że chciałaby oglądać więcej przedstawień dla dzieci.

Niektórzy z badanych pozwolili sobie także na dodatkowe opinie na temat działalności teatru ${ }^{5}$. Część $\mathrm{z}$ nich dotyczyła gry aktorskiej. W wypowiedziach pojawiły się zarówno głosy pozytywne, jak i negatywne. Jedna z badanych osób uznała, że „wszystkie spektakle w wykonaniu naszych białostockich aktorów są wyśmienite jak również w wykonaniu gości”. Inny badany napisał, że „obecny sezon teatralny pokazał że ten zespół z każdym tytułem da sobie rewelacyjnie radę z wszelkimi trudnościami, Zemsta bardzo pozytywnie mnie zaskoczyła jest to najlepsza inscenizacja obecnie w Polsce jaką widziałem". Wśród głosów negatywnych pojawiły się dwie wypowiedzi porównujące spektakle i aktorstwo Teatru Dramatycznego z propozycjami oraz możliwościami aktorskimi zespołu Białostockiego Teatru Lalek.

Widzowie podzielili się także opiniami na temat kwestii organizacyjnych. Jedna z osób uznała, że należałby wyremontować toalety i popracować nad dostępnością spektakli. Badana ta chodziłaby do teatru znacznie częściej, gdyby bilety można było kupić „spontanicznie a nie z ok. 2 miesięcznym planowaniem”.

Przedstawione opinie pokazują, że pożądany przez widzów kierunek rozwoju instytucji można byłoby określić, nawiązując do hasła promocyjnego województwa podlaskiego - „Bogactwo różnorodności”. Potrzeby widzów są bardzo różne, a więc repertuar instytucji, która chciałaby spełnić oczekiwania jak największej liczby odbiorców, powinien uwzględniać różnorodne gusta. Teatr Dramatyczny jako jedyna tego typu placówka na terenie województwa podlaskiego w przyszłości powinien oferować swoim widzom rozmaite gatunki: od sztuk klasycznych, dramatów, poprzez komedie i farsy, aż do przedstawień współczesnych - artystycznych.

W 2018 roku opinie odbiorców na temat oferty Teatru Dramatycznego udało się pozyskać także przy okazji zrealizowanego projektu „Lektury szkolne - Lubię to!”. Z myślą o pedagogach przygotowano warsztaty przybliżające tematykę spektakli szkolnych $\mathrm{z}$ repertuaru teatru. Głównym celem projektu było zainspirowanie nauczycieli, a poprzez nich także uczniów, do przyjrzenia się lekturom szkolnym $\mathrm{z}$ innej - teatralnej perspektywy. Dodatkowym celem projektu było zachęcenie nauczycieli do skorzystania z oferty teatru wraz z ich uczniami.

5 Cytaty zostały umieszczone w oryginalnej formie. 
W ramach zadania zostało przeprowadzone badanie ewaluacyjne. W zajęciach wzięło udział 114 osób, z czego 112 zgodziło się wziąć udział w badaniu ewaluacyjnym. Uczestniczkami zadania były głównie kobiety (110). W projekcie wzięło udział dwóch mężczyzn. Zdecydowana większość uczestników to osoby powyżej 35. roku życia (75 osób), pozostali byli w przedziale wiekowym od 25 do 35 lat (30 osób). Wszyscy uczestnicy mają wykształcenie wyższe magisterskie, co wynika $\mathrm{z}$ charakteru zadania i specyfiki grupy docelowej. Odbiorcami projektu byli głównie nauczyciele szkół podstawowych (101 osób), w zajęciach wzięli udział nauczyciele przedszkolni (6 osób), nauczyciele, którzy uczą zarówno w szkołach podstawowych, jak i średnich (3 osoby) oraz jeden nauczyciel ze szkoły średniej.

Dzięki badaniu udało się ustalić, iż pedagodzy bardzo wysoko ocenili zawartość merytoryczną wykładów i działań warsztatowych. Nauczyciele podkreślali, iż otrzymali konkretne narzędzia i praktyczne porady, które ułatwią im pracę z uczniami. Badanie potwierdziło, że przygotowana oferta spełniła oczekiwania uczestników. Wskazali oni także te elementy, które ich zdaniem należałoby ewentualnie ulepszyć, aby warsztaty były jeszcze bardziej atrakcyjne.

Jednak nie opinie o samych warsztatach, prowadzących, okazały się w tym badaniu najistotniejsze. Przy okazji analizy udało się pozyskać wiedzę na temat problemów, z jakimi borykają się w swojej codziennej pracy pedagodzy, i trudności, z jakimi muszą się mierzyć. Okazało się także, iż pedagodzy byli wdzięczni za możliwość spotkania $\mathrm{z}$ aktorami, reżyserami i porozmawiania o teatrze również w nieco szerszym zakresie niż tematyka warsztatów. Co udało się ustalić dzięki badaniu? W kwestionariuszach ewaluacyjnych nauczyciele podzieli się swoimi refleksjami i opiniami związanymi z uczestnictwem w życiu teatralnym. Okazało się, że część z nich ma problemy z odbiorem spektakli, mają także trudności $\mathrm{z}$ atrakcyjnym przekazywaniem uczniom wiedzy przy okazji omawiania lektur, które oglądali w formie przedstawień teatralnych. Pedagodzy obserwują problemy z odbiorem także u swoich uczniów, wspominali między innymi o nieumiejętności zachowania się dzieci i młodzieży w takim miejscu jak teatr, a także o konieczności wychowywania młodych ludzi do uczestnictwa w teatrze. Zajęcia - jak podkreślali nauczyciele - pozwoliły im lepiej zrozumieć teatr, odważniej i śmielej podejść do kwestii związanych z prowadzeniem lekcji dotyczących lektur, a także zachęciły do odwiedzin $\mathrm{w}$ teatrze i dwutorowego spojrzenia na dane dzieło literackie - z perspektywy autora i z perspektywy wizji reżysera.

Badanie ewaluacyjne projektu „Lektury szkolne - Lubię to!” uświadomiło pracownikom, jak ważna jest taka forma pozyskiwania informacji od odbiorców. Jednym z najważniejszych wniosków płynących z badania było dostrzeżenie potrzeby cyklicznego organizowania warsztatów dla pedagogów. Zajęcia skierowane do nauczycieli okazały się niezwykle pomocne w ich pracy zawodowej i zachęciły ich do wizyty w teatrze z uczniami Przełożyło się to na wzrost frekwencji i wpływy do budżetu teatru. 
Pracownicy instytucji zrozumieli, że poza statutową działalnością, jaką jest produkcja i prezentacja spektakli, teatr powinien stworzyć kompleksowy, długofalowy program działań edukacyjnych, dzięki któremu odpowiemy na rzeczywiste potrzeby pedagogów, które nie ograniczają się do obejrzenia przedstawienia wraz z uczniami. Wiedzę, jaką udało się pozyskać dzięki refleksjom i opiniom nauczycieli, wykorzystano przy skonstruowaniu kolejnego projektu „Teatr - Lubię to!”. Jesienią 2019 roku zostanie zrealizowany cykl warsztatów, który będzie miał na celu podniesienie umiejętności i kwalifikacji nauczycieli w pięciu obszarach tematycznych związanych z teatrem.

Projekt stał się okazją do nawiązania ponownej współpracy z Uniwersytetem w Białymstoku. We współpracy z Instytutem Socjologii i Kognitywistyki, który zaprojektuje badanie, zostanie przeprowadzona szczegółowa analiza. Na jej podstawie zostanie opracowany kompleksowy program edukacyjny Teatru Dramatycznego. Dzięki niemu będzie można jeszcze lepiej odpowiadać na potrzeby pedagogów i uczniów, a przede wszystkim rozpocząć długofalowy proces wychowywania przyszłych teatralnych widzów oraz szerzej - uczestników życia kulturalnego.

\section{Lakonczenie}

Opisane badania ukazują opinie i postawy względem różnych aspektów funkcjonowania Teatru Dramatycznego im. Aleksandra Węgierki w Białymstoku. Wśród respondentów znalazły się zarówno refleksje odbiorców instytucji, jak i osób, które rzadko lub wcale nie korzystają z oferty teatru. Zebrane dane na każdym etapie pracy instytucji stanowiły zachętę do analizy dotychczasowej działalności placówki, a także stały się inspiracją do dokonywania przemian.

Opinie osób odwiedzających Teatr Dramatyczny z pewnością warto brać pod uwagę, ponieważ widzowie są głównymi odbiorcami oferty teatru oraz aktywnymi uczestnikami organizowanych tu wydarzeń. Równie ważne są jednak refleksje osób, które odwiedzają dane miejsce rzadziej lub nie robią tego wcale. Krytyczne uwagi zgłaszane przez badanych, którzy nie są fanami tego konkretnego teatru, mogą stanowić początek dyskusji o roli i miejscu Teatru Dramatycznego na kulturalnej mapie Białegostoku, a także funkcji, jakie ta placówka mogłaby pełnić w przyszłości.

Zrealizowane w 2018 roku badanie było jedynie skromnym działaniem sondującym. W przyszłości instytucja powinna kontynuować diagnozę w postaci dużego projektu badawczego, analizującego potrzeby i oczekiwania widzów względem białostockiego teatru. Warto dokonać pomiaru przy użyciu narzędzi zbliżonych do tych, które zostały wykorzystane w 2012 roku. Analiza przy użyciu podobnych metod pomogłaby znaleźć odpowiedź na pytanie: jak zmieniła się ocena i postrzeganie 
instytucji, a także jak proponowany repertuar oraz inne działania artystyczne oceniają mieszkańcy województwa podlaskiego.

Badania socjologiczne czy też marketingowe są niezwykle kosztowne. Z pewnością warto w nie inwestować, ponieważ dzięki nim możemy pozyskać obiektywną wiedzę na temat realizowanych przez nas działań, a za pomocą zdobytej wiedzy próbować optymalizować działalność zarządzanej przez nas instytucji kultury. W przypadku Teatru Dramatycznego im. Aleksandra Węgierki w Białymstoku opinie zebrane w trakcie badań mogą pomóc w usprawnieniu działalności promocyjnej instytucji, dostosowaniu godzin prezentacji spektakli do potrzeb i oczekiwań odbiorców, a także pomóc w doborze propozycji repertuarowych, które sprawią, że instytucja ta będzie prezentowała jeszcze wyższy poziom artystyczny i będzie jeszcze chętniej odwiedzana przez mieszkańców.

\section{Bibliografia}

Brydniak E. (2011), Marketing Kultu(ralny) [w:] Kultura 2,4\%. Synergia różnorodności. Praca zbiorowa praktyków kultury, Warszawa: Narodowe Centrum Kultury przy wsparciu Uniwersytetu Warszawskiego, Warszawa 2011, s. 24-.

Gaweł Ł., Skowron F., Szostak A. (red.) (2019), Raport z projektu badawczego „Krakowski odbiorca kultury", Kraków: Wydawnictwo Attyka.

Instytut Kultury Miejskiej, strona internetowa, http://ikm.gda.pl/projekty/ [odczyt: 15.05.2019]. Kozłowska-Świątkowska E. (1995), Cały świat gra komedię. 50 lat Państwowego Teatru Dramatycznego im. Aleksandra Węgierki w Białymstoku, Białystok: Państwowy Teatr Dramatyczny im. Aleksandra Węgierki w Białymstoku.

Poleszczuk J., Sztop-Rutkowska K., Kiszkiel Ł., Klimczuk A., Mejsak R.J., Winiecka K. (2012), Diagnoza partycypacji w kulturze w województwie podlaskim, Białystok: Teatr Dramatyczny im. Aleksandra Węgierki w Białymstoku, Fundacja Laboratorium Badań i Działań Społecznych „SocLab”, Instytut Socjologii Uniwersytetu w Białymstoku.

Regionalny Instytut Kultury w Katowicach, strona internetowa, dostęp online: https://rik.katowice.pl/obserwatorium/badania-i-rozwoj/ [odczyt: 15.05.2019].

Zaniewska Martyna F., praca dyplomowa „Opinie widzów na temat Teatru Dramatycznego im. Aleksandra Węgierki w Białymstoku”, Akademia Humanistyczno-Ekonomiczna w Łodzi, Łódź 2018. 